PHILOSOPHY OF EDUCATION

UDC 316.3:004

DOI: https://doi.org/10.30839/2072-7941.2019.177743

\title{
THE MATRIX OF CREATIVE-INNOVATIVE POTENTIAL OF HUMAN AS A FACTOR OF FORMATION OF DIGITAL TECHNOLOGIES, DIGITAL EDUCATION AND DIGITAL ECONOMY
}

\author{
(C) NIKITENKO, V.O. \\ Engineering Institute of Zaporizhzhia National University, Editor-in-Chief (Zaporizhzhia, \\ Ukraine) \\ E-mail: vitalina2006@ukr.net, ORCID iD: 0000-0001-9588-7836
}

\begin{abstract}
The relevance of the study is that creativity is analyzed, which is the basis for the formation of creative and innovative potential of a person as a factor in the formation of an information-digital society. Goal setting is to conceptualize a person's creative and innovative potential as a factor in formation of an information-digital society, a key factor in business, education, healthcare, law, or any other field. The creative and innovative potential of man has caused and will cause profound changes in the ways of our work, in values and desires, in almost every aspect of our daily existence.

Analysis of recent research and publications. In the study we rely on the phenomenon of creativity, which are explored in the works of V. Andrushchenko, V.Bech, V.Voronkova, A.Kravchenko, S.Kutsepal, O.Kyvliuk, O.Punchenko. The focus is on Richard Florida's work, Homo creatives: How the new class is conquering the world (Kyiv, 2018). The matrix of creative-innovative potential of a person actualizes attention to the discourse-understanding of the relations "creative personality-digital society" and the influence of the informationcommunicative society on these relations. The purpose of the study is to conceptualize the creative and innovative potential of a person as a factor in the formation of an informationdigital society. The basis of the research is the conceptualization of basic schemes of creativity, which is a scientific novelty. Economy is the defining basis of a creative and digital society. Because information and innovation potential is the driving force of economic development, it is aimed at transforming the economy into a digital and innovative one by its degree of influence. Presenting main material. The analysis of formation and development of creative and innovative potential of a person as a factor of formation of information and digital society is carried out; the definition of "creative and innovative potential of a person as a factor of formation of information and digital society is presented; it is proved that the creative component is the dominant solution of problems of innovative and digital activity, including economic; conditions that contribute to the growth of human creative and innovative potential are analyzed; revealed that it represents the "creative and innovative potential of man" as a new dimension of information and digital society. The object of the research is the concept of creative and innovative potential as a new social and cultural phenomenon. The subject of the research is the influence of the information-digital society on the formation and development of creative and innovative potential. Methodology - a methodology of cultural creativity that enables the creation and development of creative and innovative potential. Conclusions - the concept of creative and innovative potential of a person as a factor of formation of information and digital society is formed
\end{abstract}

Keywords: creativity, creative and innovative potential, information and digital society, innovations, cultural creativity, digital technologies, digital education

The matrix of creative-innovative potential of human as a factor of formation of digital technologies, digital education and digital economy 
Formulation of the problem in general form and its relation to important scientific or practical tasks. Relevance of research. The relevance of the study is that creativity is analyzed, which is the basis for the formation of a person's creative and innovative potential as a factor in the formation of digital technologies. Forming a person's creative and innovative potential is that digital solutions are a priority in Ukraine, especially since digital technologies and digital companies are developing very fast, said $\mathrm{V}$. Zelensky, while on an official visit to France. Creativity and intelligence are the cornerstones of an informationdigital society that has transformed society, the economy, and culture over the last decades through the use of digital technologies. The digital technologies that underpin the information-digital society are a fundamental economic driver, gaining momentum and forming a new class the creative one, - notes Florida [16, p.13].

The emergence of this new class and the creation of creativity as a matrix of economic power were the factors underlying what appear to be unrelated and mysterious trends, such as the digital development of new industries, start-up incubators, and with it changes in expectations that structure our lives [16, p.13]. The creative class has become truly global because it covers between one third and almost half of the workforce in developed countries in North America, Europe, Asia and around the world, so there is a need to shape its matrix as an economic force [1].
The problem statement is the conceptualisation of a person's creative and innovative potential as a factor in the formation of digital technologies, which is a key factor in the field of business, education, healthcare, law or any other field. The creative and innovative potential of man has caused and will cause profound changes in the ways of human labor, values and desires, in almost every aspect of our daily existence.

The creative and innovative potential of a person is the basis for the formation of a park of high digital technologies, outsourcing of computer programs, production of knowledge and innovations, transformation of knowledge on the creativity of technology, formation of innovative infrastructure of society [2].

The matrix of creative and innovative potential of a person is formed on the basis of innovative development of society, which is based on the modernization or transformation of the economy, the creation of a national innovation system, the creation of information infrastructure, which requires the design of information-digital society and the expansion of its activities.

An analysis of the latest research and publications from which this issue is solved and which the author relies on. In the study, we rely on the matrix of creativity explored in the works of R. Andrukaytene, V.Andrushchenko, V.Bech, V.Voronkova,
A.Kravchenko,
S.Kutsepal,
O.Kivlyuk,
R.Oleksenko,
O.Punchenko, V. Starzhinsky, V. Tsepkalo, R. Florida. The focus is on 
Richard Florida's work, Homo creatives: How the new class is conquering the world (Kyiv, 2018). The matrix of creative-innovative potential of a person actualizes attention to the discourseunderstanding of the relations "creative personality-digital society" and the influence of informationcommunicative society on these relations [3].

Selection of previously unresolved parts of the general problem addressed in the article. The basis of the research is the conceptualization of basic schemas of the matrix of creativity, which is a scientific novelty. Economy is the defining basis of a creative and digital society. Because information and innovation potential is the driving force of economic development, it is aimed at transforming the economy into a digital and innovative one by its degree of influence. "Modernization as a change in values and attitudes of traditional society involves possible points of growth in the form of new approaches and paradigms.

That is why the economy of innovations can become the engine of technological and social transformations, the basis for building a competitive society,"- noted V. Starzhinsky and V. Tsekalo in his work"Towards an Innovative Society $[14$, p. 13]. It is noted that low wages are blocking the introduction of modern technology and technology, so the experience of China (Singapore), South Korea, Taiwan, Malaysia can be instructive and important to us in terms of development in which the services sector is formed around the industrial manufacturing sector of the economy and generally reflects its structure [4].

The purpose and formulation of the goals of the article (formulation of the task).

The purpose of the study is to conceptualize the matrix of human creative and innovative potential as a factor in the formation of digital technologies. The key objective of the study is to unveil the creative energies, talents and potential of each person, who we instill in the creative and innovative potential of the individual as the main resource of the information-digital society.

Using the methodology of design and cultural creation, it is necessary to assess how economic success is happening, which can be an environment and a factor in the development of digital technologies of information and digital society, how foreign countries have made the leap from leaders to losers and become competitive due to the technological development of their countries [5].

\section{Objectives of the study:}

- to analyze the formation and development of the matrix of human creative and innovative potential as a factor in the formation of digital technologies of information and digital society;

- to present the definition of matrix of creative and innovative potential of a person as a factor of formation of information and digital society;

- to prove that the matrix of the creative component is the dominant solution of problems of innovative and digital activity, including economic;

The matrix of creative-innovative potential of human as a factor of formation of digital technologies, digital education and digital economy 
- to analyze the conditions that contribute to the growth of creative and innovative potential of the person;

- to discover what constitutes a "creative and innovative potential of man" as a new dimension of digital technologies of information and digital society.

The object of study is the matrix of creative and innovative potential as a new social and cultural phenomenon.

The subject of the research is the influence of digital technologies on the formation and development of creative and innovative potential.

\section{Research methodology}

systematic and structural-functional, synergetic analysis of problems of creative-innovative potential of a person as a factor of formation of digital technologies of informationdigital society. Methodology - the methodology of cultural creation, which allows for the formation and development of the matrix of creative and innovative potential of man and society.

\section{Discussion of the problem.}

Outline of the main research material with justification of scientific results.

The analysis of formation and development of the matrix of creative and innovative potential of a person as a factor of formation of informationdigital society is carried out. Technology, which is a breakthrough in the achievement of technology and technology to become competitive [6]. So, in just a couple of decades, the technological breakthrough has made Singapore, whose leader Li Quan Yu not only brought his country from the "third world" to the "first" in terms of living, but also bypassed the United States. Malaysian leader Mahathir Mohammad, 22 years in leadership, has shown that the country is capable of an "economic miracle", demonstrating to the world that Muslims are technically capable of inventing and amazed at the success of developed countries. Modernized countries - Taiwan, Singapore, South Korea, Malaysia for 20-30 years have become on par with developed Western countries, based on the development of which the priority matrix of creative and innovative potential as a new social and cultural phenomenon [7].

The definition of matrix of creative-innovative potential of the person as a factor of formation of digital technologies of informationdigital society, which underlies technological breakthrough is presented. The creative and innovative potential of a person as a factor in the formation of digital technologies is a collection of information, knowledge, technologies, know-how, creative industries leading to the overall prosperity and unprecedented growth of the creative person, creative economy and creative society, including the development of human potential, and atomized, deterministic human behavior that encompasses a person's ability to make choices that are satisfied with personal growth, improvement about their healthy physical fitness, a development that is at the forefront of post-materialist politics - the transition from values that favor immediate material needs, to the quality of the environment, to diversity, to social cohesion and quality of life, which is a factor in the 
creative economy and the identity that leads to the most creative and to the highest productivity [8].

It is proved that the matrix of creative component is the dominant solution of problems of innovative and digital activity, including economic. A key driving force is the rise of human creativity as a determinant of the creative economy and society. The Collarless Workplace is the latest stage in the evolution of society towards the use of digital technologies, more effective ways of promoting ideas of creativity that are levers of influence on the "collective mind", through the creation of the physical and social context that creativity needs. The creative economy is driven solely by change and speed [9].

If a company wants to survive, it must exceed its performance "yesterday". Its employees must constantly produce new ideas, gradually develop faster, cheaper and more efficient ways to do different things, and the company inspires them to do their best. Creative workers respond well to organizations that offer stable values, clear rules, open communication, good working conditions and fair use. Creative work cannot be guided or "streamlined" in army order; it should be free because employees are committed to the company with dedication and enjoyment [12].

The new digital economy has emerged as a social force capable of transforming both people and society; as a result, there was an internal internalization of work called "soft control", which helped to "support digital progress." The new digital economy has formed new powerful information and digital culture, which has taken over the minds of people, has become a norm of self-expression and self-actualization, which has generally led to the transformation of the entire business and digital culture [10].

Digital companies have developed a unique creative management scheme based on three relevant principles: 1) to help employees do their jobs as best they can by intellectually engaging them in a process that does not distract or impede their productivity; 2) to make managers responsible for stimulating creativity rather than forging different rules; 3 ) to involve clients as creative partners to make sure the products the company develops meet their needs [13]. The managerial scheme creates a corporate ecosystem in which the matrix of creativity and productivity flourishes and profitability and flexibility go hand in hand, - notes Florida [16, p. 123].

The willingness and desire of managers to immerse them in "real" creative work shows that there is one company in the companies that works to achieve the goal and to create the best product. As an example, $26 \%$ of the company's budget is spent on research and development, which is almost double the average of high technology companies. The main goal of companies is to gather creative talents from both clients and employees and form the concept of the company's creative team. [14].

Conditions that contribute to the growth of human creative and

The matrix of creative-innovative potential of human as a factor of formation of digital technologies, digital education and digital economy 
innovative potential are analyzed. The key to understanding the new economic geography and positive impact on digital metrics is what $\mathrm{R}$. Florida calls the three "T" matrices of digital development: technology, talent, tolerance that contributes to digital breakthroughs and the adoption of cross-cutting technologies [11]. The interdependence of these three factors explains why certain companies contribute to the formation and development of a technological base that contributes to technological and digital breakthroughs. The most successful companies combine the three $\mathrm{T}$ matrixes [16]. Scientists agree that the technology matrix is a key factor in the development of the digital society, and that technological advancement allows society to radically change itself by isolating the technology matrix as a leading force in development. Innovations such as computer software, robotics, biotechnology and the improvement of production systems and processes make technology and the economy more efficient and productive for society and society.

Silicon Valley, which houses the most famous and most revolutionary technology companies - from Intel, Apple. Cisco to Google and Facebook and which is the largest venture capital center. However, in 2010, according to the Technology Index, Silicon Valley hegemony challenged Seattle with its suburbs, where Microsoft, Amazon and many other companies are located, which allowed the city to take the first rank [14].

In second place is San Jose, followed by San Francisco with suburbs that came to the fore as key tech companies and talented people began to prioritize creative technology in urban locations: Portland in fourth place, Austin - on the fifth, followed by Rally, San-Diego and Durham, Boston and Boulder scored in the top ten. [16] It is the universities located in these states that communicate with the business structures and academic communities of the universities, between which there is a correlation between the creative class and technology [16, p. 220-221]. The creative class accounts for over $35 \%$ of the workforce in 14 of the top 20 cities in the Technology Index, and exceeds $40 \%$ in six of them. The creative class correlates with all the metrics and dimensions of the hightech industry and digital innovation [15].

It is revealed that it represents the "matrix of creative and innovative potential of a person" as a new dimension of information and digital society includes highly educated, ambitious individuals who are called "human potential", which belongs to the Creative class, which is the central force of digital development and stimulation of innovations.

Most economists tend to regard technology and talent as fixed assets as raw materials and natural resources that are able to generate economic growth in certain regions through new digital industries and gain creative advantage.

The Creativity Index for the Global Economic Growth Index includes three indexes: the Technology Index, the Talent Index and the Tolerance Index [16, p. 240]. The Matrix of Creative and Innovative Human Potential "as a new dimension 
of the information and digital society includes dimensions such as education and engagement in science, talent and creativity, mastery of certain skills and abilities that contribute to changes in productivity, high barriers to human capital penetration high-tech industries and high-tech breakthroughs.

Conclusions of the study. The concept of creative-innovative potential of a person as a factor of formation of information-digital society is formed, based on which the introduction of high digital technologies, transition to an innovative paradigm not only of economic but also social modernization, improvement of social relations of state construction, use of the potential of e-government, for $\mathrm{h}$ egovernment paradigm "state in the smartphone". The e-government project has at its core anti-corruption potential, as well as benefits related to ease of communication, mobility, responsiveness, accessibility, time saving, which is designed to rebuild the mentality of managers and develop a new style of communication with public authorities.

Practical recommendations.

1. Practice the use of information and computer and digital technologies for operational management when making management decisions in organizations, firms and enterprises.

2. Introduce environmentally friendly technological processes that help to increase the efficiency of information and digital technologies.

3. Protect information from unauthorized access.
4. Facilitate the development of mechanisms for implementing innovative digital projects and involve venture companies that can assist with the implementation of innovative projects.

5. The state should use organizational, financial and intellectual resources to develop an innovative digital economy and knowledge economy in order to create the conditions for the development of digital businesses that can be effective under the right conditions of use.

6. To develop the information structure of digital technologies, whose needs are growing in connection with the development of high-tech digital technologies.

7. To develop innovative trends in digital IT technologies and competences, for which it is necessary to carry out the program of effective training of professional specialists in the most advanced industries and effective programs of professional development of personnel in all disciplines.

8. To contribute to the development of strategic goals of socio-economic development of Ukraine, based on the priority of education as an element of IT infrastructure, the development of high technologies and new trends in digital technologies.

9. Conducts an innovative educational policy aimed at the development of digital education, based on information technology and the implementation of the concept of innovative digital education.

10. To develop start-up projects as an element of IT infrastructure, in

The matrix of creative-innovative potential of human as a factor of formation of digital technologies, digital education and digital economy 
which there is a system of measures for finding business ideas and providing organizational, financial and other support to companies that are at the initial stage of their development.

11. Implement a cluster approach to creating a digital business environment as an organizational form of innovation development that will help to increase the competitiveness of regions and industries through the use of cluster methodology.

12. Promote the development of qualified standards in IT and education

\section{REFERENCES}

1. Andriukaitiene Regina, Cherep A.V., Voronkova V. H., Punchenko O. P., Kyvliuk O. P. (2018). Managing organizational culture as a factor in organizational change. Humanities bulletin of Zaporizhzhia state Engireering academy, 75, 169 - 179.

DOI https://doi.org/10.30839/2072-7941.2018.155562

2. Andriukaitiene, Regina, Janulionis, Ernestas and Voronkova, Valentyna (2019). The concept of corporate social responsibility and its implementation in the activity of organizations. Humanities Bulletin of Zaporizhzhia State Engineering Academy, 76, 184-196.

DOI: https://doi.org/10.30839/2072-7941.2019.165128

3. Voronkova, V. (2004). Municipal Management: Teaching manual Kiev: Professional, 254.

4. Voronkova, V. H., Maksymeniuk, M. Yu., Nikitenko, V. O. (2017). Formation of noosphere world as the basis of information and innovation noosphere, noosphere economy and society. Gileiâ, 122, 159-162.

5. Maksimenûk, M. YU., Nikitenko, V.O. (2016). The formation of the paradigm of information-communicative society as a kind of complex social systems and interaction. Humanities bulletin of Zaporizhzhe state engineering academy, 66, 266-278.

6. Melnyk, V. V. (2014). Hlobalizatsiia v kulturniy sferi: teoretyko-metodolohichnyi analiz. Gileiâ, 86, 219-225.

7. Melnyk, V. V. (2011). The socio-philosophical analysis of the influence and interaction of individual and globalised society. Humanities bulletin of Zaporizhzhia state engineering academy, 46, 96-108.

8. Nikitenko V.O. Modern geokultura as a geokulturnij phenomenon // Humanities bulletin of Zaporizhzhia state engineering academy, 53, 261-270.

9. Nikitenko, V.O. (2013). Problem field of the geokul' turnogo phenomenon: scientific approaches. Gileiâ, 71, 500-504.

10. Punčenko, O. P. (2007). The strategy of the construction and development of the information society. Prospects. Sir. Philosophy, sociology, political science, 2, 30.

11. Ryzhova, I. S. (2017). Smart - technologies as the factor of development of modern design. Humanities bulletin of Zaporizhzhia state engineering academy, 69 (1), 174-183.

12. Ryzhova, I. S. (2011). Culture is the most fundamental way of human existence. Humanities bulletin of Zaporizhzhe state engineering academy, 46, 126-134. 
13. Ryzhova, I. S. (2009). Design in technical high schools. Humanities bulletin of Zaporizhzhe state engineering academy, 3, 87-95.

14. Starzhinsky, V. P. (2016). Towards an Innovation Society. Minsk: RIVSh, 446.

15. Sosnin, O. V., Nikitenko, V. O. and Maksymeniuk, M. Yu. (2017). Informaitsinokomunikatyvnyi menedzhment: zarubizhnyi i vitchyznianyi menedzhment. Kyiv: «Politekhnika», 316.

16. Floryda, R. (2018). Homo creatives: Yak novyi klas zavoiovuie svit. Kyiv: Nash formyt, 432.

НІКІТЕНКО, В. О. - кандидат філософських наук, доцент, доцент кафедри менджменту організацій та управління проектами, Інженерний інститут Запорізького національного університету (Запоріжжя, Україна)

E-mail: vitalina2006@ukr.net, ORCID iD: 0000-0001-9588-7836

\title{
МАТРИЦЯ КРЕАТИВНО-ІННОВАЦІЙНОГО ПОТЕНЦІАЛУ ЛЮДИНИ ЯК ЧИННИК ФОРМУВАННЯ ЦИФРОВИХ ТЕХНОЛОГІЙ, ЦИФРОВОЇ ОСВІТИ ТА ЦИФРОВОї ЕКОНОМІКИ
}

\begin{abstract}
Анотація. Актуальність дослідження в тому, що проаналізовано креативність, що $\epsilon$ основою формування креативно-інноваційного потенціалу людини як чинник формування інформаційно-цифрового суспільства. Постановка завдання концептуалізація креативно-інноваційного потенціалу людини як чинник формування інформаційно-цифрового суспільства, що $є$ ключовим чинником у царині бізнесу, освіти, охорони здоров'я, права чи в будь-якій іншій галузі. Креативно-інноваційний потенціал людини спричинив і буде спричиняти докорінні зміни у способах нашої праці, у цінностях і бажаннях, практично в кожному аспекті нашого щоденного буття.

Аналіз останніх досліджень і публікацій. В дослідженні ми спираємося на феномен креативності, що досліджуються в роботах В.Андрущенка, В.Беха, В.Воронкової, А.Кравченко, С.Куцепал, О.Кивлюк, Р.Олексенка, О.Пунченка. Головна увага зосереджена на роботі Річарда Флориди «Ноmo creatives: Як новий клас завойовує світ» (Київ, 2018). Матриця креативно-інноваційного потенціалу людини актуалізує увагу на дискурсосмисленні взаємовідносин «креативна особистістьцифрове суспільство» та впливу інформаційно-комунікативного суспільства на ці взаємовідносини.
\end{abstract}

Мета дослідження - концептуалізація креативно-інноваційного потенціалу людини як чинник формування інформаційно-цифрового суспільства. В основі дослідження - концептуалізація базових схем креативності, що представляє собою наукову новизну. Економіка $\epsilon$ визначальною основою креативно-цифрового суспільства. Оскільки саме інформаційно-інновацний потенціал є рушійною силою економічного розвитку, так як за ступенем свого впливу він направлений на те, щоб трансформувати економіку в цифрову та інноваційну.

Виклад основного матеріалу. Здійснено аналіз становлення і розвитку креативноінноваційного потенціалу людини як чинника формування інформаційно-цифрового суспільства; представлено визначення «креативно-інноваційного потенціалу людини як чинник формування інформаційно-цифрового суспільства; доведено, що креативна складова $\epsilon$ домінантою вирішення проблем інноваційно-цифрової діяльності, включаючи економічну; проаналізовано умови, що сприяють зростанню креативноінноваційного потенціалу людини; виявлено, що являє собою «креативно-інноваційний потенціал людини» як новий вимір інформаційно-цифрового суспільства. Об'єкт дослідження - концепт креативно-інноваційного потенціалу як новий соціальний і

The matrix of creative-innovative potential of human as a factor of formation of digital technologies, digital education and digital economy 
культурний феномен. Предмет дослідження - вплив інформаційно-цифрового суспільства на становлення i розвиток креативно-інноваційного потенціалу. Методологія - методологія культуротворчості, що дає можливість для становлення і розвитку креативно-інноваційного потенціалу.

Висновки - сформовано концепцію креативно-інноваційного потенціалу людини як чинника формування інформаційно-цифрового суспільства і креативних технологій.

Ключові слова: креативність, креативно-інноваційний потенціал, інформаційноцифрове суспільство, інновації, культуротворчість, цифрові технології.

Никитенко, В.А. - кандидат философских наук, доцент, доцент кафедры менеджмента организаций и управления проектами, Инженерный институт Запорожского национального университета (Запорожье, Украина)

E-mail: vitalina2006@ukr.net, ORCID iD: 0000-0001-9588-7836

\title{
МАТРИЦА КРЕАТИВНО-ИННОВАЦИОННОГО ПОТЕНЦИАЛА ЧЕЛОВЕКА КАК ФАКТОР ФОРМИРОВАНИЯ ЦИФРОВЫХ ТЕХНОЛОГИЙ, ЦИФРОВОГО ОБРАЗОВАНИЯ И ЦИФРОВОЙ ЭКОНОМИКИ
}

\begin{abstract}
Аннотация. Актуальность исследования в том, что проанализирована креативность, которая есть основой формирования креативно-иновационного потенциала человека и фактор формирования инновационно-цифрового общества.Постанвока задания - концептуализация креативно-инновационного потенциала человека как фактор формирования инновационно-цифрового общества, которая есть ключевым фактором в сфере бизнеса, образования, охраны здоровья, права или в любой отрасли. Креативно-инновационный потенциал человека осуществил и букет осуществлять коренные изменения в способах нашого труда, в ценностях, желаниях, практически в каждом аспекте нашей повседневной жизни. Анализ последних исследований и публикаций. В исследовании мы опираемся на феномен креативности, который исследуется в работах В.Андрущенко, В.Беха, В.Воронковой, А.Кравченко, С.Куцепал, О.Кивлюк, Р.Олексенко, О.Пунченко. Главное внимание сосредоточено на работе Ричардла Флориды «Нomo creatives: Как новый класс завоевывает мир» (Киев, 2018). Матрица креативно-инновационного потенциала человека актуализирует внимание на дискурсосмыслении взаимоотношений «креативная личность-цифровое общество» и влияния информационнокоммуникативного общества на эти взаимоотношения.

Цель исследования - концептуализация креативно-инновационного потенциала человека как фактор формирования информационно-цифрового общества. В основе исследования - концептуализация базових схем креативности, которая представляет собой научную новизну. Экономика есть определяющей основой кративно-цифрового общества. Поскольку именно информационно- инновационный потецниал есть движущей силой экономического развития, так как по мере свого влияния он направлен на то, чтобы трансформировать экономику в цифровую и инновационную.
\end{abstract}

Изложение основного материала. Осуществлен анализ становления и развития креативно-инновационного потенциала как фактор формирования информационноцифрового общества; доказано, что креативная составляющая есть доминантой решения проблем инновационно-цифровой деятельности, включая эекономическую; проанализированы условия, которые содействуют росту креативно-инновационного потенциала человека; выявлено, что представляет собой «креативно-инновационный потенциал человека» как новое измерение информационно-цифрового общества. Объект исследования -матрица креативно-инновационного потенциала как новый 
социальный и культурный феномен. Предмет исследования - влияние информационноцифрового общества на становление и развитие креативно-инновационного потенциала. Методология - методология культуротворчества, которая дает возможность для становлення и развития креативно-инновационного потенциала.

Выводы - сформирована концепция креативно-инновационного потенциала человека как фактор формирования информационно-цифрового общества и креативных технологий.

Ключевые слова: креативность, креативно-инновационный потенциал, информационно-цифровое общество, инновации, культуротворчество, цифровые технологии, цифровое образование.

Стаття рекомендована до публікаиії

д.філософ.н., проф. О. П. Кивлюк (Київ, Україна)

Надійшла до редколегії: 10.06.2019

Прийнята до друку: 15.06.2019

The matrix of creative-innovative potential of human as a factor of formation of digital technologies, digital education and digital economy 